\title{
EFEKTIVITAS PEMANFAATAN SISTEM INFORMASI MANAJEMEN DINAS TENAGA KERJA KOTA PALANGKA RAYA
}

\author{
Harija Putra
}

\begin{abstract}
ABSTRAK
Sistem Informasi Manajemen mempunyai peran penting dalam memenuhi kebutuhan manusia dalam sebuah organisasi. Sistem Informasi Manajemen berguna untuk menyajikan informasi guna memberikan fungsi operasi, manajemen, dan pengambilan keputusan. Dalam skripsi ini, penulis mengangkat tema tentang Efektivitas Pemanfaatan Sistem Informasi Manajemen Dinas Tenaga Kerja Kota Palangka Raya. Penelitian ini bertujuan untuk mengetahui efektivitas organisasi tersebut dalam memanfaatkan Sistem Informasi Manajemen, serta faktor-faktor apa saja yang mempengaruhi. Dalam penelitian ini, jenis penelitian yang digunakan adalah penelitian kualitatif. Disini peneliti melakukan pengamatan awal atau penjelajahan umum di lokasi penelitian yaitu di lingkungan Dinas Tenaga Kerja Kota Palangka Raya untuk memperoleh gambaran menyeluruh tentang latar belakang masalah, sehingga memudahkan peneliti menentukan sumber data penelitian. Sumber data yang digunakan peneliti adalah sumber data primer, dimana sumber data primer ini diminta langsung dari informan atau narasumber, serta data sekunder berupa dokumen-dokumen yang dibutuhkan untuk menjadi data pendukung. Teknik pengumpulan data yang digunakan dalam penelitian ini adalah dengan melakukan observasi, wawancara dan dokumentasi. Dalam menganalisi data, peneliti menggunakan reduksi data yaitu data dikumpul kemudian dipilah dan disederhanakan agar mudah menentukan data ke dalam fokus indikator penelitian. Dalam penelitian ini, peneliti mengukur efektivitas dengan teori Emitai Etzioni dalam Akhmad Subekhi dan Mohammad Jauhar (2013:252), yaitu pengukuran efektivitas yang disebut "system model" mencakup empat kriteria yaitu Kriteria Adaptasi, Kriteria Integrasi, Kriteria Motivasi, dan Kriteria Produksi. Berdasarkan hasil penelitian sesuai dengan rumusan masalah, pemanfaatan Sistem Informasi Manajemen Dinas Tenaga Kerja Kota Palangka Raya sudah berjalan dengan efektif, karena dari hasil penelitian berupa jawaban serta tanggapan informan terkait dengan indikator efektivitas, dalam bentuk pelayanan dan pelaksanaan kegiatan yang dilakukan oleh Dinas Tenaga Kerja Kota Palangka Raya sudah memenuhi kriteria efektivitas.
\end{abstract}

Kata Kunci : Sistem Informasi Manajemen, Efektivitas

\section{PENDAHULUAN}

Perkembangan teknologi yang begitu pesat, merupakan realitas kehidupan yang tidak mungkin dapat dihindari sebagai dampak dari globalisasi. Keterkaitan 
antara globalisasi dan teknologi ini dapat diartikan seperti sebuah simbiosis mutualisme, dimana dengan tidak mungkin globalisasi dapat menjarah keseluruh pelosok negeri tanpa adanya suatu teknologi. Begitu pula sebaliknya tidak mungkin suatu teknologi dapat berkembang pesat dan canggih tanpa ada bantuan informasi dari globalisasi. Di dalam sebuah organisasi dikenal ada 2 sumber daya, yaitu sumber daya fisik dan konseptual berupa informasi. Sumber daya konseptual sangat penting dalam menunjang kelangsungan hidup suatu organisasi.

Masalah sistem informasi berhubungan dengan karakteristik informasi. Hasil dari sistem informasi harus dapat digunakan untuk kegiatan managemen ditingkat operasional, taktis dan strategik. Jika tidak dapat digunakan, informasi tersebut layak untuk tidak diperhatikan lagi. Dalam suatu masalah harus ada pemecahannya. Pemecahan masalah merupakan tindakan yang dilakukan untuk menangani permasalahan yang ada dalam sistem informasi, dimana istilah pemecahan masalah mengingatkan pada perbaikan hal-hal yang salah.

Dinas Tenaga Kerja Kota Palangka Raya menyajikan informasi-informasi ketenagakerjaan lewat website yang mereka miliki. Informasi tersebut berupa lowongan pekerjaan, persyaratan-persyaratan pembuatan kartu kuning atau kartu pencari kerja, serta informasi sosialisasi dan pelatihan tenaga kerja. Menurut seorang informan Dinas Tenaga Kerja Kota Palangka Raya, informasi yang mereka sajikan tidak tersaji seperti yang mereka harapkan dikarenakan kurangnya akses dari masyarakat. Maka dari itu terkait dengan penyajian informasi, peneliti ingin meneliti bagaimana efektivitas pemanfaatan sistem informasi manajemen oleh Dinas Tenaga Kerja Kota Palangka Raya. Adapun tujuan yang ingin diwujudkan dalam penelitian ini untuk mendeskripsikan dan menganalisa bagaimana Efektivitas Pemanfaatan Sistem Informasi Manajemen Dinas Tenaga Kerja Kota Palangka Raya dan faktor-faktor apa saja yang mempengaruhinya.

\section{LANDASAN TEORI}

Menurut Robbins (1994: 53) efektivitas organisasi didefinisikan sebagai sejauh mana organisasi mewujudkan tujuan-tujuannya. Etzioni (1964), mengemukakan pengukuran efektivitas organisasi yang disebut dengan "system model" mencakup empat kriteria yaitu Kriteria Adaptasi, Kriteria Integrasi , Kriteria Motivasi , Kriteria Produksi. Subekhi dan Jauhar (2013: 254) mengatakan bahwa "pengukuran efektifitas organisasi sesungguhnya harus mencakup berbagai kriteria, yaitu efisiensi, kemampuan menyesuaikan diri dengan tuntutan perubahan adaptasi, integrasi, motivasi dan produksi".

Menurut Robbins (1994: 67) "organisasi merupakan suatu entitas sosial yamg terkoordinasi secara sadar, terdiri dari dua orang atau lebih dengan batasan yang relatif teridentifikasi, yang berfungsi secara berkelanjutan untuk mencapai seperangkat sasaran bersama" (Torang, 2016: 25).

Scott (1996: 69) mengatakan "sistem terdiri dari unsur-unsur seperti masukan (input), pengolahan (processing), serta keluaran (output) (Anwar dan Oetojo, 2004: 5). Suradinata (1996: 3) menjelaskan bahwa "sistem merupakan suatu himpunan komponen atau variabel yang terorganisasi, saling bergantung satu sama lain dan terpadu, serta tidak dapat dipandang sebagai suatu komponen yang terpisah-pisah". 
Pengertian informasi seperti yang dikemukakan oleh Grudnitski (1986: 3) "informasi adalah sebagai data yang telah diletakkan dalam konteks yang lebih berarti dan berguna yang dikomunikasikan pada penerima untuk digunakan dalam pembuatan keputusan". Menurut McLeod (1996: 68) "Informasi adalah data yang telah diproses atau data yang memiliki arti.

George R. Terry dalam bukunya yang berjudul "Principles of Management" memberikan definisi "Manajemen adalah suatu proses yang membedakan atas perencanaan, pengorganisasian, penggerakan pelaksanaan dan pengawasan, dengan memanfaatkan baik ilmu maupun seni, agar dapat menyelesaikan tujuan yang telah ditetapkan sebelumnya."

Menurut Kertahadi (1995: 5) "Sistem Informasi Manajemen dapat didefinisikan sebagai suatu alat untuk menyajikan informasi dengan cara demikian rupa sehingga bermanfaat bagi penerimanya". Gordon B. Davis dalam Kerthadi (1995: 11) Sistem Informasi Manajemen adalah sistem informasi yang selain melakukan semua pengolahan transaksi yang perlu untuk sebuah organisasi, juga memberi dukungan informasi dan pengolahan untuk fungsi manajemen dan pengambilan keputusannya.

\section{METODE PENELITIAN}

Jenis penelitian yang digunakan dalam penelitian ini adalah penelitian kualitatif. Menurut Poerwandri (1998) "penelitian kualitatif adalah penelitian yang menghasilkan dan mengolah data yang sifatnya deskriptif, seperti transkripsi wawancara, catatan lapangan, gambar, foto, rekaman video, dan lain-lain" (Afifuddin dan Saebani, 2012: 130). Penelitian ini berfokus kepada indikator efektivitas sebagai berikut: Kriteria Adaptasi, Kriteria Integrasi, Kriteria Motivasi, Kriteria Produksi. Penelitian ini juga mendeskripsikan faktor pendukung dan penghambat efektivitas. Penelitian ini dipusatkan di Kantor Dinas Tenaga Kerja Kota Palangka Raya, maka peneliti memilih lokasi di Kantor Dinas Tenaga Kerja Kota Palangka Raya, Jln. Tjilik Riwut km. 6,5, Kelurahan Bukit Tunggal, Kecamatan Jekan Raya, Kota Palangka Raya, Kalimantan Tengah. Teknik pengumpulan data adalah wawancara, observasi dan dokumentasi. Adapun teknik analisa data sesuai dengan Miles \& Huberman (1984) dalam Sugiyono (2014: 247) mengemukakan tiga tahapan yang harus dikerjakan dalam menganalisis data penelitian kualitatif, yaitu: "(1) reduksi data (data reduction); (2) penyajian data (data display); dan (3) penarikan kesimpulan dan verifikasi (conclusion drawing / verifying)". Analisis data kualitatif dilakukan secara bersamaan dengan proses pengumpulan data berlangsung, artinya kegiatan-kegiatan tersebut dilakukan juga selama dan sesudah pengumpulan data.

\section{PEMBAHASAN}

\section{Kriteria Adaptasi}

Kemampuan suatu organisasi untuk menyesuaiakan diri dengan lingkungannya. Untuk hal itu antara lain digunakan tolak ukur proses pengadaan dan pengisian tenaga kerja serta ruang lingkup kegiatan organisasi tersebut. Dinas Tenaga Kerja Kota Palangka Raya sudah menggunakan sistem online dalam 
penyediaan informasi ketenagakerjaan dan perangkat keras/lunak yang sudah diperbaharui, juga tersedia website milik Dinas Tenaga Kerja Kota Palangka Raya yang bisa diakses oleh masyarakat untuk mencari informasi ketenaga kerjaan. Dari hasil penelitian menunjukkan bahwa kriteria adaptasi Dinas Tenaga Kerja Kota Palangka Raya dalam Pemanfaatan Sistem Informasi Manajemen sudah cukup berjalan dengan efektif.

\section{Kriteria Integrasi}

Pengukuran terhadap kemampuan suatu organisasi untuk menjadikan sosialisasi pengembangan konsensus dan komunikasi dengan beberapa macam organisasi lainnya. Sebuah organisasi dapat melakukan aktivitas operasionalnya dengan baik apabila orang-orang yang ada di dalamnya saling berinteraksi atau bekerja sama dalam mewujudkan efektivitas sistem informasi organisasi. Untuk menciptakan kerjasama yang baik sangat diperlukan komunikasi karena apabila efektivitas sistem informasi manajemen dapat terwujud maka dengan sendirinya kerjasama yang baik dapat diciptakan. Dari hasil penelitian menunjukkan bahwa kriteria integritas Dinas Tenaga Kerja Kota Palangka Raya dalam Pemanfaatan Sistem Informasi Manajemen sudah cukup efektif, ditandai dengan adanya kerjasama dengan organisasi-organisasi lain di Kota Palangka Raya, terkait dengan penyediaan informasi Dinas Tenaga Kerja Kota Palangka Raya menggunakan Sistem Informasi Ketenagakerjaan dalam menyediakan informasi lapangan kerja dan informasi pelatihan kerja.

\section{Kriteria Motivasi}

Pengukuran mengenai keterkaitan dan hubungan antara perilaku organisasi dengan organisasinya dan kelengkapan sarana bagi pelaksanaan tugas pokok dan fungsi organisasi. Organisasi pada dasarnya dijalankan oleh manusia, maka penilaian kinerja sesungguhnya merupakan penilaian atas perilaku manusia dalam melaksanakan peran yang mereka mainkan di dalam organisasi. Dari hasil penelitian menunjukkan bahwa dilihat dari aspek pelayanan kepada masyarakat, kriteria motivasi terkait Pemanfaatan Sistem Informasi Manajemen Dinas Tenaga Kerja Kota Palangka Raya sudah cukup baik. Telah disediakan jaringan Wi-Fi untuk menunjang operasional untuk menunjang penggunaan Sistem Informasi Ketengakerjaan. Untuk pegawai yang terlambat absen fingerprint sistem online akan mendapatkan sanksi. Telah dijelaskan bahwa sesuai dengan peraturan Walikota akan ada denda dalam bentuk pemotongan tunjangan kinerja, termasuk jika pegawai melakukan pelanggaran yang sengaja atau akibat kelalaian dan melanggar ketentuan dalam perjanjian kerja.

\section{Kriteria Produksi}

Pengukuran efektivitas organisasi dihubungkan dengan jumlah organisasi dan mutu-mutu keluaran organisasi serta intensitas kegiatan suatu organisasi. Peranan efektivitas manajemen biasanya diakui sebagai faktor paling penting dalam keberhasilan jangka panjang suatu organisasi. Keberhasilan diukur dalam bentuk pencapaian sasaran organisasi. Berdasarkan gasil penelitian, pelayanan publik terkait kegiatan yang dilakukan Dinas Tenaga Kerja Kota Palangka Raya 
sudah cukup baik. Hal tersebut dengan alasan bahwa kegiatan yang dilakukan di Dinas Tenaga Kerja Kota Palangka Raya sudah cukup produktif karena di dukung oleh sarana yang bagus.

\section{PENUTUP}

\section{Kesimpulan}

Pada bab sebelumnya yaitu pada bagian pembahasan telah diuraikan hasil penelitian tentang Efektivitas Pemanfaatan Sistem Informasi Manajemen Dinas Tenaga Kerja Kota Palangka Raya. Kesimpulannya adalah pemanfaatan Sistem Informasi Manajemen di Dinas Tenaga Kerja Kota Palangka Raya sudah efektif, ditandai dengan telah terpenuhinya 4 kriteria efektivitas yaitu :

1. Kriteria Adaptasi

2. Kriteria Integrasi

3. Kriteria Motivasi

4. Kriteria Produksi

Faktor-faktor yang mempengaruhi Efektivitas Pemanfaatan Sistem Informasi Manajemen Dinas Tenaga Kerja Kota Palangka Raya adalah :

1. Faktor Pendukung

a. Sumber Daya Aparatur

b. Sarana dan Prasarana

2. Faktor Penghambat : Kesadaran Masyarakat

\section{Saran}

a. Diharapkan Dinas Tenaga Kerja Kota Palangka Raya membenahi website Dinas Tenaga Kerja agar menjadi lebih baik dan menarik sehingga membuat masyarakat makin tertarik untuk berkunjung, serta membuat aplikasi berbasis Android tentang informasi ketengakerjaan Kota Palangka Raya, agar memudahkan akses informasi oleh masyarakat melalui smartphone.

b. Diharapkan agar Dinas Tenaga Kerja Kota Palangka Raya tidak hanya memperbaharui software dan hardware penunjang sistem informasi yang diperlukan, juga memperbaharui dan meningkatkan sistem keamanan sistem informasi dengan meningkatkan firewall jaringan dan anti-virus komputer yang ada di Dinas Tenaga Kerja Kota Palangka Raya.

\section{DAFTAR PUSTAKA}

Afifuddin, H. \& Saebani, Ahmad Beni. 2012. Metodologi Penelitian Kualitatif. Bandung: Pustaka Setia, cv

Akadun. 2011. Teknologi Informasi Administrasi. Bandung: Alfabeta

Akadun. 2014. Organisasi \& Manajemen. Bandung: Alfabeta

Anwar, Khoirul M. \& Oetojo, Asianti. 2004. SIMDA : Aplikasi Sistem Informasi Manajemen bagi Pemerintah di Era Otonomi Daerah. Malang: Pustaka Pelajar 
Burch, John \& Grudnitski, Gary. 2006. Teori Sistem Informasi dan Praktik. Yogyakarta: Garaha Ilmu

Daryanto \& Abdullah. 2013. Pengantar Ilmu Manajemen dan Komunikasi. Jakarta: Prestasi Pustaka

Davis, Gordon B. 2002. Kerangka Dasar Sistem Informasi Manajemen. Jakarta: PT Pustaka Binaman Pressindo

Denzin, Norman K. \& Yvona S. Lincoln (eds.). 2009. Handbook of Qualitative Research.

Terj. Dariyatno dkk. Jogjakarta: Pustaka Pelajar

Etzioni, Amitai. 1964. Modern Organization. New Jersey: Pretince Hall

Glaser, Barney G. \& Strauss, Anselm L. 1967. The Discovery of Grounded Theory: Strategies for Qualitative Research. USA: AldineTransaction

Herlambang, Soendoro \& Tanuwijaya, Haryanto. 2005. Sistem Informasi Manajemen (Konsep, Teknologi, dan Manajemen).Yogyakarta: Garaha Ilmu

Kerthadi. 1995. Sistem Informasi Manajemen. Malang: IKIP Malang

Kirk, J. \& Miller, M. L. 1986. Reliability and Validity in Qualitative Research. London : Sage Publications

Kusuma, Hendra. 2001. Manajemen Produksi : Perencanaan dan Pengendalian Produksi. Yogyakarta: Andi

McLeod, Raymond Jr. 1996. Management Information Systems. New Jersey: Pretince Hall

Miles, M. B. \& Huberman, A. M. 1984. Scientific Research Publishing. London: Sage Publications

Moleong, J. Lexy. 2012. Metodologi Penelitian Kualitatif. Bandung: PT Remaja Rosdakarya

Patton, M. Q. 1998.Discovering Process Use. London : Sage Publications

Poerwandari, E. K. 1998. Pendekatan Kualitatif dalam Penelitian Psikologi. Jakarta: LPSP3 Fakultas Psikologi Universitas Indonesia

Rhama, B. (2020). The meta-analysis of Ecotourism in National Parks. African Journal of Hospitality, Tourism and Leisure, 9(1), 1-17.

Rhama, B. and Reindrawati, D. Y. (2019). Geotour Guide Competency in the Context of Safety Management. Opción, 35(24), 885-899. .

Rhama, B. (2019). Psychological Costs on Tourism Destination. Journal of Advanced Management Science, 7(3), 100-106. doi: 10.18178/joams.7.3.100-106

Rhama, B. (2018). The Analysis of the Central Kalimantan Tourism Development Plan Based on Ecotourism Policy Perspective. Policy \& Governance Review, 2(3), 204-016. doi:10.30589/pgr.v2i3.110

Rhama, B. (2014). Hubungan Antara Nilai Yang Dimiliki Stakeholder Terhadap Pengembangan Kebijakan Ekowisata Pada Taman Nasional Di Indonesia. JISPAR, 3(2), 47-73. doi:10.17605/OSF.IO/3ZYNH 
Rhama, B. (2013). Kebijakan Pengembangan Sumber Daya Manusia Bidang Pariwisata di Kalimantan Tengah. JISPAR, 2(2), 18-23. doi:10.17605/OSF.IO/27KV5

Rhama, B. (2012). Kebijakan Publik Untuk Ekowisata di Kalimantan Tengah: Kebijakan Penataan Kawasan Ekowisata Sungai Kahayan di Kota Palangka Raya. JISPAR, 1(1), 47-51. doi:10.17605/OSF.IO/T4W2U

Robbins, S. P. 1994. Teori Organisasi (Struktur, Desain, dan Aplikasi). Jakarta. Erlangga

Scott, George M. 1996. Prinsip-Prinsip Sistem Informasi Manajemen. Depok: RajaGrafindo Persada

Subekhi, Akhmad \& Jauhar, Mohammad. 2013. Pengantar Teori \& Perilaku Organisasi. Jakarta: Prestasi Pustaka.

Sugiyono. 1994. Metode Penelitian Administrasi. Bandung: Tarsito

Sugiyono. 2014. Metode Penelitian Kuantitatif Kualitatif Dan R\&D. Bandung: Alfabeta

Suradinata, Ermaya. 1996. Sistem Informasi Manajemen Proses Pengambilan Keputusan.

Bandung: CV Ramadan

Surjadi, H. 2012. Pengembangan Kinerja Pelayanan Publik. Bandung: PT Refika Aditama

Torang, Syamsir. 2016. Organisasi \& Manajemen. Bandung: Alfabeta

Waluyo. 2007. Manajemen Publik. Sumedang: Mandar Maju. 